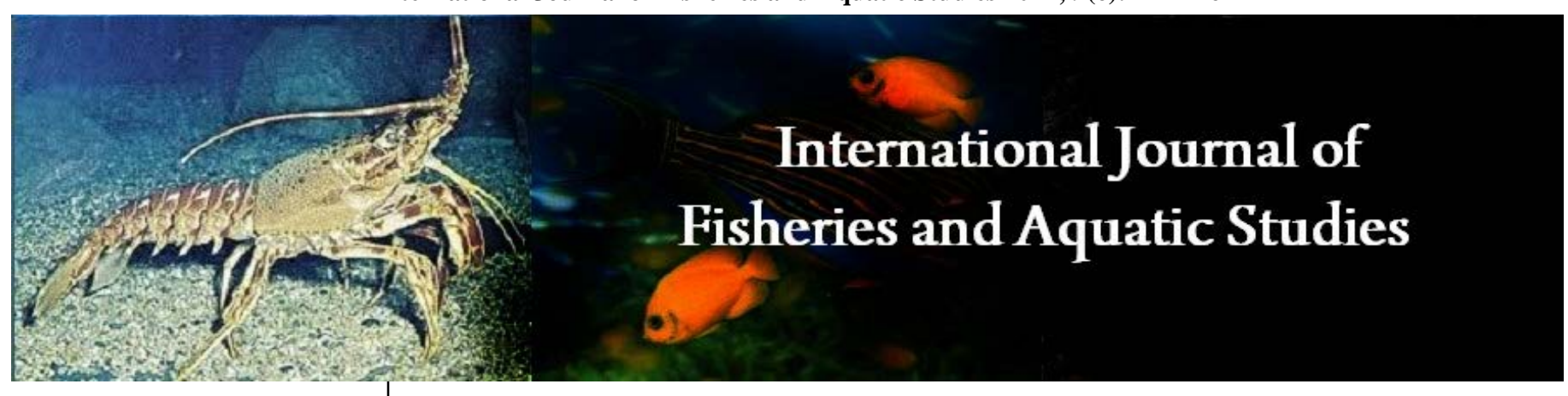

E-ISSN: 2347-5129

P-ISSN: 2394-0506

(ICV-Poland) Impact Value: 5.62

(GIF) Impact Factor: 0.549

IJFAS 2021; 9(6): 222-226

(C) 2021 IJFAS

www.fisheriesjournal.com

Received: 19-09-2021

Accepted: 21-10-2021

Mohosena Begum Tanu

Chief Scientific Officer,

Headquarters, Bangladesh

Fisheries Research Institute,

Mymensingh 2201, Bangladesh

Arun Chandra Barman

Senior Scientific Officer,

Headquarters, Bangladesh

Fisheries Research Institute,

Mymensingh 2201, Bangladesh

Mohammad Ferdous Siddique

Senior Scientific Officer,

Headquarters, Bangladesh

Fisheries Research Institute,

Mymensingh 2201, Bangladesh

Sonia Sku

Senior Scientific Officer,

Freshwater Station, Bangladesh

Fisheries Research Institute,

Mymensingh 2201, Bangladesh

Md. Nazmul Hossen

Scientific Officer, Freshwater

Station, Bangladesh Fisheries

Research Institute, Mymensingh

2201, Bangladesh

Abu Rayhan

Scientific Officer, Freshwater

Station, Bangladesh Fisheries

Research Institute, Mymensingh 2201, Bangladesh

Yahia Mahmud

Director General, Bangladesh

Fisheries Research Institute,

Mymensingh 2201, Bangladesh

Corresponding Author:

Sonia Sku

Senior Scientific Officer,

Freshwater Station, Bangladesh

Fisheries Research Institute,

Mymensingh 2201, Bangladesh

\section{Determining of suitable size of paraffin image for image pearl production in freshwater mussel (Lamellidens marginalis) in Bangladesh}

\author{
Mohosena Begum Tanu, Arun Chandra Barman, Mohammad Ferdous \\ Siddique, Sonia Sku, Md. Nazmul Hossen, Abu Rayhan and Yahia Mahmud
}

DOI: $\underline{\text { https://doi.org/10.22271/fish.2021.v9.i6c.2605 }}$

\begin{abstract}
An experiment was carried out to produce image pearl from February 2016 to September 2016 in freshwater mussel (Lamellidens marginalis) of 9-10cm length. This experiment was set to find out the suitable size of paraffin image for better quality image pearl production by inserting different size of paraffin image. A total of five hundred mussels were operated with paraffin image of different size $3.5 \mathrm{~cm}$ $\left(\mathrm{T}_{1}\right), 3 \mathrm{~cm}\left(\mathrm{~T}_{2}\right), 2.5 \mathrm{~cm}\left(\mathrm{~T}_{3}\right), 2 \mathrm{~cm}\left(\mathrm{~T}_{4}\right)$, and $1.5 \mathrm{~cm}\left(\mathrm{~T}_{5}\right)$ by netbag hanging method in cistern and pond of Freshwater station, BFRI research complex, Mymensingh. The stocking density of operated mussel was 100 per decimal. Physicochemical parameters of the culture pond (Temperature, DO, Alkalinity, pH, Ammonia, Calcium, and Phytoplankton) were recorded at 15 days interval and found in a suitable range for mussel culture. Operated mussels were observed monthly to know the survival rate. After 8 months of culture survival rate of mussel was observed highest in treatment $\mathrm{T}_{3}(49 \%)$ followed by $\mathrm{T}_{4}(21 \%), \mathrm{T}_{5}$ (19\%), $T_{2}(16 \%)$, and $T_{1}(13 \%)$, respectively. Image pearl formation with high luster and nacre layer $0.47 \pm 0.01 \mathrm{~mm}$ was found premier from treatment $\mathrm{T}_{3}$ whether the nacre layer was found $0.23 \pm 0.02 \mathrm{~mm}$, $0.31 \pm 0.01 \mathrm{~mm}, 0.41 \pm 0.01 \mathrm{~mm}$, and $0.43 \pm 0.01 \mathrm{~mm}$ from $\mathrm{T}_{1}, \mathrm{~T}_{2}, \mathrm{~T}_{4}$, and $\mathrm{T}_{5}$ respectively. A thick nacre layer, the shiny luster of image pearl with a high survival rate of mussel was found in treatment $\mathrm{T}_{3}$. In that case, it can be said that $2.5 \mathrm{~cm}$ size of paraffin image is suitable for image pearl culture in the freshwater mussel.
\end{abstract}

Keywords: paraffin image, image pearl, nacre layer, culture method

\section{Introduction}

Pearls were the first gems discovered by man thousands of years ago. Since that time, people of many cultures have recognized the beauty and value of pearls. Pearls are the only organic gems and require no processing to reveal their natural beauty (Haws 2002) ${ }^{[3]}$. Pearl is a very precious gem that is created in a living organism called mussel. When a pearl is produced as a picture format or image format it is called image pearl. Different materials of image (bird, fish, flower, etc.) inserted into the mussel body and its secrets nacre to cover the image, and then the paraffin made image turns into image pearl. Image pearl has accordant characteristics to the original sculpture covered by the shiny pearl layer which is one of the most attractive crafts of adoration (Dan et al., 2001) ${ }^{[1]}$. This pearl is used not only as jewelry but also in decoration pieces, value-added products, and other purposes. For sea pearl production there is a weakness of high cost, business collapse risk, and a long forming time, starting from 1.5 to 3 years. Comparing to the seawater pearl, freshwater pearl production costs relatively low, pearl formation takes less than 1 year and pearl produced with different colors (Rachman et al., 2006) ${ }^{[10]}$. Image pearl can be produced within a short time (7-8 months) with very easy operation procedures by costing low price. Due to the favorable weather of Bangladesh, the prospect of pearly mussel, pearl culture is bright and promising with high economic value. There are numerous ponds, lake, haor, baor, beels, bays, and estuaries in Bangladesh which can be devoted to mussel culture as well as pearl production (Dan et al., 2001) ${ }^{[1]}$. Around 95\% of the world's produced freshwater pearl comes from China (Mamangkey et al., 2009) ${ }^{[7]}$. In Bangladesh, pearl culture has a great potentiality but practical information has not been commercially established yet (Sarker, 1994) ${ }^{[13]}$. Freshwater mussels, which are used for pearl 
culture, can be cultured in the fish pond and other suitable water bodies. Mussels filters the water as water cleaner, therefore, the pearl culture is environment friendly. Pearl culture can be conducted in any kind of water bodies like ponds, lakes, rivers, reservoirs, etc. So, it is easy to extend in a rural area with low input and high output (Hossain et al., 2004) ${ }^{[4]}$. A survey report termed the history and present status of natural pearl culture and suggested the bright prospect of pearl culture in Bangladesh (Mazid 2001) [6]. Production rate and quality of image pearl depend on the operated mussel species, inserting image size and operation techniques. The quality of pearl also depends on the environment such as water depth, water quality, natural food, etc. is also important to the pearl culture (Hossain et al., 2004) [4]. An image pearl is also known as a flat pearl and it can be used for different purposes. Though the paraffin made image takes more space compared to the mantle tissue and nuclei insertion that is why the insertion of different sizes image can influence the production of image pearl quality. In that case, this experiment was set to find out the suitable size for image pearl production.

\section{Materials and Methods Cistern and Pond preparation}

Rectangular cistern with a dimension of $(2.42 \mathrm{~m} \times 1.88 \mathrm{~m} \times 1 \mathrm{~m})$ having a water exchange facility was used for the post and pre-treatment of the mussels after disinfected by $\mathrm{KMnO} 4$. The pond was organized through the regular pond preparation procedure. Organic and inorganic fertilizers were applied to fertilize the pond at the rate of $5 \mathrm{~kg} / \mathrm{decimal}$, T.S.P $0.125 \mathrm{~kg} /$ decimal, and Urea $0.1 \mathrm{~kg} /$ decimal. Lime was applied at $0.5 \mathrm{~kg} /$ decimal. The depth of water and pond area was $1-1.5$ meter and 5-decimal.

\section{Collection, selection and rearing of mussel for operation}

Healthy, disease-free, having a yellow edge on the outer part of the shell of mussels were collected from different places of the country. From the collected species, Lamellidens marginalis was selected for image operation. The average length and width of selected stocked mussels were 9-10 cm and 4-5 cm for operation. Based on survival rate and pearl production $L$. marginalis was identified as the suitable species (Hossain et al., 2004) ${ }^{[4]}$. L. marginalis was used for image pearl culture due to its size, availability, and suitability to operate. After selection, mussels were stocked in a prepared pond, reared, and nourished to make healthy and eligible for the operation.

\section{Pre conditioning of selected mussel}

Selected mussels were preconditioned without feeding in a disinfectant cistern for 7-days. Water was changed on regular basis to remove the clay from the outer shell and inner soft body of the mussel. Before the operation, mussels were brought to the laboratory and kept them a downward position on a porous basket for two hours to reduce the water from the internal organ of mussel.

\section{Paraffin image preparation}

Dead shell of the mussel, soybean oil, paraffin, heather, and needle were used to prepare image. Soybean oil was applied on the concave side of the dead shell to pick up the paraffin image from the shell easily. Then the liquid wax was poured on the oil layer of the concave side of the shell and shakes one side to another for making a thin layer $(1.5-3.5 \mathrm{~mm})$ of wax.
After that, an image or sculpture was designed with a needle.

\section{Instruments for experiment}

To operate on the mussels for culturing image pearls, the following special instruments were used:

1. Wooden stand: This stand was used to keep the mussel in a fixed position. So, the operator can handle the mussel easily.

2. Dead Shell: A dead shell was used to prepare the image

3. Mussel opener: Made of stainless steel. This was used to open the shells of mussels and prevent them from closing before the introduction of the paraffin image.

4. Staple: To prevent closing of the open-shell of the mussel

5. Different size of the image: It was made by paraffin wax

6. Spatula: Made of stainless steel with a flat end. It was used to make a pocket between the mantle and shell of a mussel

7. Miscellaneous: Different chemicals including 70\% ethanol, potassium per-manganite (KMnO4) used as disinfectant for the apparatus. Distilled water used to clean tray and bowls for keeping the operated mussel safely.

\section{Operation method}

Before image insertion, the paraffin images were washed by distilled water to remove dirt. The selected live mussel was opened about $8 \mathrm{~mm}$ with the help of a mussel opener. A little area of the attached mantle was detached from the shell by spatula cautiously to make a space as the size of inserting the image. Then the image was inserted into the cavity between the shell and mantle of the mussel. After insertion, the image was adjusted in the cavity and gently removed the air from the cavity area. Finally, the operated mussels were kept at an upward position on the tray till transfer to the cistern so that the image cannot come out.

\section{Post conditioning of operated mussel}

After the operation, mussels were conditioned in a cistern for 7- days without feeding. Water was changed regularly in the cistern. The next 21 days fed with collected plankton from the pond and then transferred to the pond.

\section{Culture and stocking management of mussel}

Operated mussels were stocked in the prepared culture pond with a density of 100 mussel/ decimal. A total of 500 operated mussels were cultured in an experimental pond by the net bag hanging method for 8 months. Six operated mussels were stocked in six pockets of a rectangular shaped net bag and hanged by the rope till $30-35 \mathrm{~cm}$ depth with a float. The rope stretched across the pond on the surface of the water. The distance between two bags was $25-30 \mathrm{~cm}$ and rope to rope distance was $1.5 \mathrm{~m}$. Organic and inorganic fertilizer was applied fortnightly to the pond at the rate of $5 \mathrm{~kg}$ organic manure, $0.125 \mathrm{~kg}$ T.S.P. and $0.1 \mathrm{~kg}$ urea per decimal. Operated mussels were checked monthly during culture in the pond. The survival rate was checked once a month. Water temperature, $\mathrm{pH}$, plankton growth, $\mathrm{NH} 4-\mathrm{N}, \mathrm{DO}$, and $\mathrm{Ca}^{2+}$ parameters were recorded fortnightly.

\section{Experimental design}

Lamellidens marginalis was used for the experiment. The average length and width of mussels were 9-10 cm and 4$5 \mathrm{~cm}$. Operated mussels cultured by net bag hanging method in 
cistern and pond. A total of 500 mussels were operated with different sizes of paraffin images. Five treatments were set with five different lengths of image $1.5 \mathrm{~cm}\left(\mathrm{~T}_{1}\right), 2 \mathrm{~cm}\left(\mathrm{~T}_{2}\right)$,
$2.5 \mathrm{~cm}\left(\mathrm{~T}_{3}\right), 3 \mathrm{~cm}\left(\mathrm{~T}_{4}\right), 3.5 \mathrm{~cm}\left(\mathrm{~T}_{5}\right)$ while the common width of paraffin image was $1.5 \mathrm{~cm}$. In each treatment, 100 mussels were operated.

Table 1: Design of the experiment

\begin{tabular}{|c|c|c|c|c|c|c|}
\hline Treatment & $\begin{array}{c}\text { Size of } \\
\text { Image }\left(\mathrm{cm}^{2}\right)\end{array}$ & $\begin{array}{c}\text { Number of } \\
\text { operated mussel }\end{array}$ & $\begin{array}{c}\text { Length of } \\
\text { mussel (cm) }\end{array}$ & $\begin{array}{c}\text { Width of } \\
\text { mussel }(\mathrm{cm})\end{array}$ & $\begin{array}{c}\text { Name of culture } \\
\text { method }\end{array}$ & $\begin{array}{c}\text { Mussel used for } \\
\text { Operation }\end{array}$ \\
\hline $\mathrm{T}_{1}$ & $3.5 \times 1.5$ & 100 & \multirow{5}{*}{$9-10$} & & \multirow{5}{*}{$\begin{array}{l}\text { Rotational hanging in } \\
\text { cistern and pond }\end{array}$} & \multirow{5}{*}{$\begin{array}{l}\text { Lamellidens } \\
\text { marginalis }\end{array}$} \\
\hline $\mathrm{T}_{2}$ & $3.0 \times 1.5$ & 100 & & & & \\
\hline $\mathrm{T}_{3}$ & $2.5 \times 1.5$ & 100 & & $4-5$ & & \\
\hline $\mathrm{T}_{4}$ & $2.0 \times 1.5$ & 100 & & & & \\
\hline$T_{5}$ & $1.5 \times 1.5$ & 100 & & & & \\
\hline
\end{tabular}

\section{Monitoring of water quality parameters}

Management of water quality is very much important during the culture period, which affects the image pearl qualitatively and quantitatively. Water should be pollution and diseasefree. The water quality parameter such as temperature $\left({ }^{\circ} \mathrm{C}\right)$ was measured by Celsius thermometer, $\mathrm{pH}$ by digital $\mathrm{pH}$ meter (Jenway, model 3020), dissolved oxygen (mg/L) with digital Oxygen-meter (YSI, model 58), ammonia (mg/L) by using an ammonia testing kit (HACH test kit (FF-3 model), $\mathrm{Ca}^{2+}$ measured by Flame photometer (Buck Scientific FPF-7) and phytoplankton $\left(\times 10^{3} \mathrm{cell} / \mathrm{l}\right)$ counted with Sedwick-Rafter (S-R) cell. The samples were always collected from the subsurface with minimum disturbance of the mussels.

\section{Statistical analysis}

All the collected data were analyzed statistically and expressed as mean and ( \pm ) standard deviation using SPSS package 25.0 software

\section{Results and discussion}

\section{Mussel and Pearl harvesting}

After 8 month of rearing mussels were harvested from culture pond and washed thoroughly with clean water to remove algae and other unwanted materials attached on its shell. After cleaning mussels were sacrificed and removed all the soft body parts to collect the image pearl attach on its internal shell.

\section{Survival rate}

After 8 month of culture image pearl were harvested. Survival rate and nacre layer data were recorded after harvest. The most important factor that limits freshwater pearls is high mortality of the mussel after insertion into the mussel ( $\mathrm{Li}$ and Li 2009) ${ }^{[5]}$.From above table 2, highest survival rate of operated mussel was found $49 \%$ in treatment $\mathrm{T}_{3}$ while treatment $T_{1}$, treatment $T_{2}$, treatment $T_{4}$ and treatment $T_{5}$ survival rate found $13 \%, 16 \%, 21 \%$ and $19 \%$ respectively. Survival rate of mussels were negatively correlated with the inserted different size of image (Figure 1). In June death occurred 20\% and then lowered after August for pearl culture in Parreysia Corrugata (Suryawanshi and Kulkarni2015) ${ }^{[14]}$ while, 55-95\% survival rate in freshwater mussel (Margaritifera falcate) found by Fernandez (2013) ${ }^{[2]}$. In case of treatment $\mathrm{T}_{3}$, convex part of inserted paraffin image was matched properly with concave part of mussel shell. Because of matching inserted image couldn't move excessively. On the other hand, treatment $T_{5}$ was small comparing with the 9$10 \mathrm{~cm}$ length of mussel and it didn't match with the concave part of mussel in time. So, this inserted image exit from the mussel and died for more movement and so that survival rate found very poor. Survived mussel took more time to match with inserted image. In case of treatment $T_{5}$, it didn't match with the concave part of live mussel and took more place of muscle part of mussel. So, mussels were wound more, nacre secretion and survival rate was found very poor.

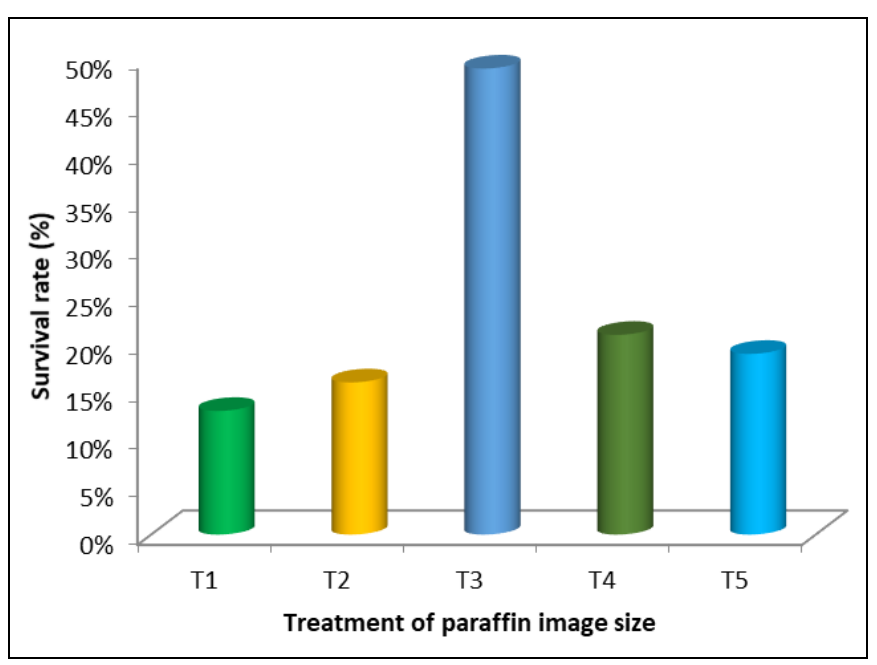

Fig 1: Survival rate of mussel in different treatment.

\section{Image pearl production}

From the experiment it was found that, image pearl were produced in all survived image containing mussel which were inserted by different size of image $(3.5 \mathrm{~cm}, 3 \mathrm{~cm}, 2.5 \mathrm{~cm}, 2 \mathrm{~cm}$, $1.5 \mathrm{~cm})$, but nacre layer, luster, color was different from each other. Image pearl color, nacre layer was found better in treatment $\mathrm{T}_{3}(2.5 \mathrm{~cm})$. Inserted image was matched properly and couldn't move excessively. For that reason nacre layer $(0.47 \pm 0.3)$ spread properly on the inserted image and the size, shape and design of the image was clearly visible. Accumulations of nacre layer in mussels were negatively correlated with the different treatment (Table 2). The success rate of pearl formation in mantle cavity recorded at $60-70 \%$ (Janakiram, 1997) ${ }^{[11]}$. In case of treatment $\mathrm{T}_{1}(3.5 \mathrm{~cm})$, it didn't match with the concave part of live mussel and took more place of muscle part of mussel. On large size image, nacre secretion of mussel was very low, that's why it was broken by little bit finger pressure while on small size image nacre secretion of mussel was very high, and it was found shapeless image pearl. Comparing with different size of image treatment $\mathrm{T}_{3}(2.5 \mathrm{~cm})$ was perfect for $9-10 \mathrm{~cm}$ size of mussel where image color, luster, nacre layer $(0.47 \pm 0.01)$ and other criteria was better. The maximum and minimum thickness of nacreous layer was found 0.35 and $0.20 \mathrm{~mm}$ respectively in mantle cavity implantation method (Pandey and Singh 2015) ${ }^{[9]}$. The color of the half round pearl generally follows the color of the interior shell which was lead to golden to silvery or yellow and pinkish to whitish (Janakiram 1997) ${ }^{[11]}$. The primary color of freshwater pearls 
is white and those account for more than 60 percent of all output. Other colors include orange, red, green, black and purple. Pearl color relates to the host mussel, the cell slices inserted and the minerals in the water ( $\mathrm{Li}$ and $\mathrm{Li}, 2009)^{[5]}$.

Table 2: Pearson's correlation among the treatments of image pearl production in freshwater mussel, $L$ marginalis.

\begin{tabular}{|c|c|c|c|c|}
\hline Correlations & Size of image & Nacre layer & Survival rate & Pearl production rate \\
\hline Size of image & 1 & $-0.970^{* *}$ & -0.554 & -0.554 \\
\hline Nacre layer & $-0.970^{* *}$ & 1 & 0.721 & 0.721 \\
\hline Survival rate & -0.554 & 0.721 & 1 & $1.000^{* *}$ \\
\hline Pearl production rate & -0.554 & 0.721 & $1.000^{* *}$ & 1 \\
\hline
\end{tabular}

**. Correlation is significant at the 0.01 level (2-tailed).

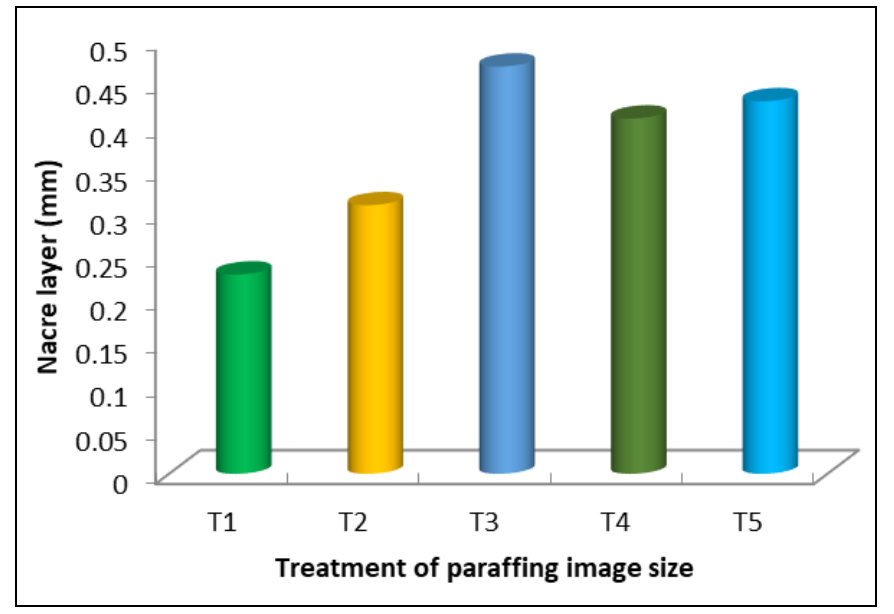

Fig 2: Nacre layer in mm of produced image pearl in different treatment

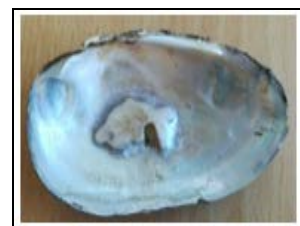

$\mathrm{T}_{1}$

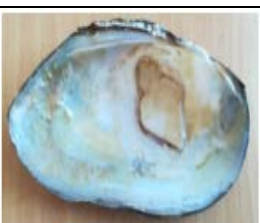

$\mathrm{T}_{2}$

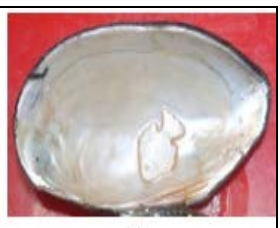

$\mathrm{T}_{3}$

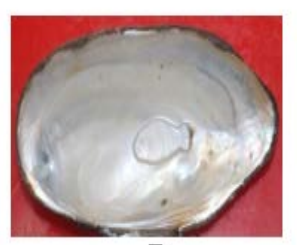

$\mathrm{T}_{4}$

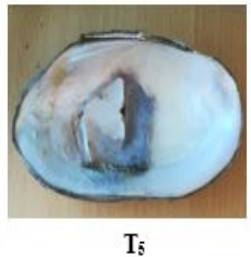

$T_{5}$
Fig 3: Produced image pearl from five treatments

\section{Water quality parameter}

Physicochemical parameter was monitored at 15 days interval. During monitoring all the water quality parameter were found in suitable range (Figure 4). Temperature was ranged from $27.88 \pm 1.71^{\circ} \mathrm{C}$, DO ranged from $5.53 \pm 0.62 \mathrm{mg} / \mathrm{l}$, alkalinity found $188 \pm 48.23 \mathrm{mg} / \mathrm{l}, \mathrm{pH}$ found $7.3 \pm 0.70$, Ammonia 0.003 \pm 0.002 , calcium ion ranged from $18.12 \pm 4.25$ $\mathrm{mg} / \mathrm{l}$ and $68.25 \pm 7.06 \times 10^{3}$ cell/l which ranges are suitable for mussel and fish culture. Ideal range for mussel culture is in temperature $15-30^{\circ} \mathrm{C}$, pH 6.5-8.5, DO 5-8 mg/l, alkalinity 50$300 \mathrm{mg} / \mathrm{l}$, ammonia $0.03-0.1 \mathrm{mg} / \mathrm{l}$, phytoplankton $\left(\times 10^{3}\right.$ cell/l) 50-100 and calcium over 10mg/l (Dan et al., 2001) ${ }^{[1]}$. During freshwater mussel (Lamellidens marginalis) culture in pond water, Natarajan and Susithira (2015) ${ }^{[8]}$ found temperature, $\mathrm{pH}$, dissolve oxygen, $\mathrm{Ca}^{2+}$ and alkalinity ranging from 25.40 $28.80{ }^{\circ} \mathrm{C}, 7.1$ - 7.9, $5.3 \mathrm{mg} / \mathrm{l}$ - $6.8 \mathrm{mg} / \mathrm{l}, 58.90 \mathrm{mg} / \mathrm{l}$ - 71.20 $\mathrm{mg} / \mathrm{l}$ and $399.00 \mathrm{mg} / \mathrm{l}$ - $594.00 \mathrm{mg} / \mathrm{l}$. For Pearl culture Janakiram (1997) ${ }^{[11]}$ found $\mathrm{pH}$ 7.5-8.5 and alkalinity 75150.The water quality parameter (temperature 29.99 \pm 0.20 , dissolve oxygen $5.63 \pm 0.29$, pH $8.16 \pm 0.12$, Phytoplankton $89.817 \pm 12.4 \times 10^{3}$ cell/l) measured in aquaculture area of pearl production found suitable by Yulianto et al., (2016) ${ }^{[15] .}$ Rathor (2017) [12] recorded water quality parameter (temperature $25.3 \pm 1.55{ }^{0} \mathrm{C}$, pH $6.4 \pm 0.21$, dissolve oxygen $5.63 \pm 0.17 \mathrm{ml} / \mathrm{l}$, Alkalinity 22.44 $\pm 0.34 \mathrm{mg} / \mathrm{l})$ during Lamellidens corrianus culture for pearl production. Pandey and Singh (2015) ${ }^{[9]}$ observed the water quality parameter suitability at temperature $23.5-36.0^{\circ} \mathrm{C}, \mathrm{pH} 7.5-8.5$, dissolve oxygen $9.5-10.85 \mathrm{mg} / \mathrm{l}$, alkalinity 220-275 mg/l, ammonia 0.053-0.065 mg/l for optimum growth of mussel throughout the culture period.

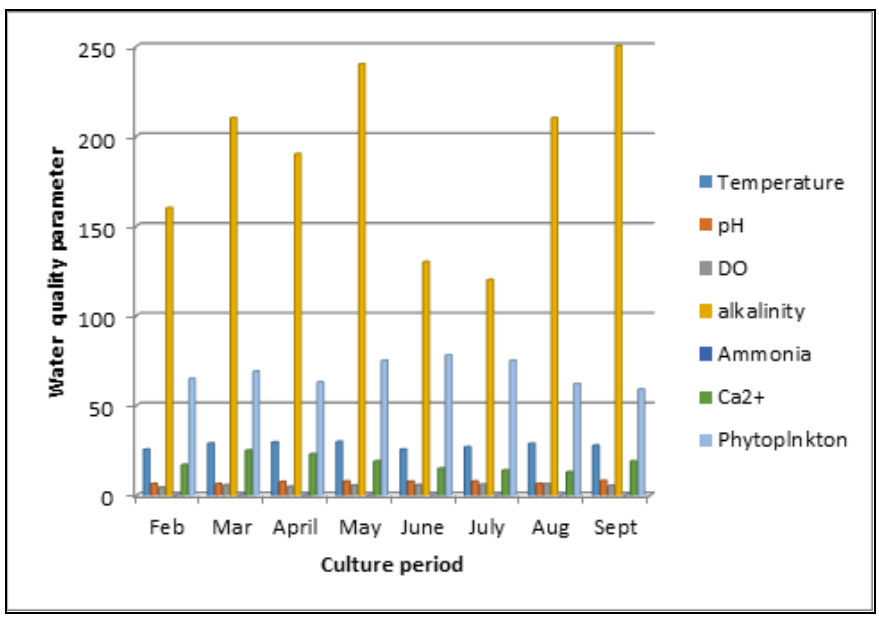

Fig 4: Water Quality parameter

\section{Conclusion}

At the end of experiment it can be said that, image pearl can produced from different size of paraffin image but better quality image pearl can formed from $2.5 \mathrm{~cm}$ size of paraffin image in $9-10 \mathrm{~cm}$ length $L$. marginalis. Large size of image causing high mortality and smaller size of image takes long time to set at concave part of mussel shell and by this time it can be excluded effortlessly. Finally it can be concluded that better quality of image pearl with high luster, high amount of nacre layer, good shape and design and high survival rate observed in $2.5 \mathrm{~cm}$ of paraffin image.

\section{References}

1. Dan H, Mazid MA, Hussain MG. Freshwater Pearl Culture: Principles and Techniques. Bangladesh Fisheries Research Institute, Mymensingh 2201. 2001

2. Fernandez MK. Transplants of western pearl shell mussels to unoccupied streams on willapa national wildlife refuge, Southwestern Washington. Journal of Fish and Wildlife Management 2013;4(2):316-325.

3. Haws M. The Basics of Pearl Farming: A Layman's Manual. Center for Tropical and Subtropical Aquaculture. Publication 2002, 127. 
4. Hossain MA, Sultana N, Azimuddin K, Hussain MG, Mazid MA. Selection of freshwater pearl mussel species for mantle transplantation in Bangladesh. Bangladesh Fisheries Research Institute, Mymensingh Bangladesh J Fish. Res 2004;8(2):113-116.

5. Li J, Li Y. Aquaculture in China- Freshwater pearl culture. Journal of the World Aquaculture Society 2009;40(1):60-62.

6. Mazid MA. (ed.). Present status and development potential of pearl culture in Bangladesh.A survey report. Bangladesh Fisheries Research Institute, Mymensingh 2201 2001, 42.

7. Mamangkey NGF, Salmon HA, Southgate PC. Use of Anesthetics with the Silver Lip Pearl Oyster, Pinctada maxima (Jameson). Aquaculture 2009;288:280-284.

8. Natarajan N, Susithira R. Physico-chemical Characteristics of Water Quality for Culturingthe Freshwater Mussel Lamellidens marginalis in Pond and Laboratory. IOSR Journal of Pharmacy and Biological Sciences 2015;10(6):11-14.

9. Pandey A, Singh A. Freshwater pearl culture: Scope and importance in North-West states of India. International Journal of Physical Education 2015;10(2):43-45.

10. Rachman B, Winanto T, Maskur. Effect of various depth against implantation process and nucleus coating pearls in oysters Margaritifera sp. on controlled pool. Impasja 2006;2:86-95.

11. Janakiram. "Freshwater pearl culture in India," Naga, The World Fish Center 1997;20(3, 4):12-17.

12. Rathor VS. Induced designer pearl production in freshwater mussel Lamellidens corrianus. Journal of Science and Technological Researches 2017;1(4):16-19.

13. Sarker MN. Status and potential of pearl fishery of Bangladesh. Journal of Shellfish Research 1994;13:325355.

14. Suryawanshi AV, Kulkarni AN. Nacre secretion with respect to temperature in freshwater Bivalve Parreysia Corrugata from Nanded Region, Maharashtra. International Journal Pure Applied Bioscience 2015;3(4):33-36.

15. Yulianto H, Hartoko A, Anggoro S, Delis PC. Suitability analysis of pearl oyster farming in Lampung Bay, Pesawaran, Lampung Province, Indonesia. AACL Bioflux 2016;9(6):1208-1219. 